\title{
REVIEW
}

\section{Circulating tumor cells and DNA as liquid biopsies}

\author{
Ellen Heitzer', Martina Auer', Peter Ulz', Jochen B Geigl' and Michael R Speicher ${ }^{1 *}$
}

\begin{abstract}
For cancer patients, the current approach to prognosis relies on clinicopathological staging, but usually this provides little information about the individual response to treatment. Therefore, there is a tremendous need for protein and genetic biomarkers with predictive and prognostic information. As biomarkers are identified, the serial monitoring of tumor genotypes, which are instable and prone to changes under selection pressure, is becoming increasingly possible. To this end, circulating tumor cells (CTCs) or circulating tumor DNA (ctDNA) shed from primary and metastatic cancers may allow the non-invasive analysis of the evolution of tumor genomes during treatment and disease progression through 'liquid biopsies.' Here we review recent progress in the identification of CTCs among thousands of other cells in the blood and new high-resolution approaches, including recent microfluidic platforms, for dissecting the genomes of CTCs and obtaining functional data. We also discuss new ctDNA-based approaches, which may become a powerful alternative to CTC analysis. Together, these approaches provide novel biological insights into the process of metastasis and may elucidate signaling pathways involved in cell invasiveness and metastatic competence. In medicine these liquid biopsies may emerge to be powerful predictive and prognostic biomarkers and could therefore be instrumental for areas such as precision or personalized medicine.
\end{abstract}

\section{Monitoring cancer therapy}

Improvement in the clinical outcome of many cancer types is likely to be achieved by giving patients a drug tailored to the genetic makeup of their tumor. One of the best documented examples is the breast cancer drug trastuzumab (Herceptin), a monoclonal antibody that blocks the human epidermal growth factor receptor 2

*Correspondence: michael.speicher@medunigraz.at

'Institute of Human Genetics, Medical University of Graz, Harrachgasse 21/8, A-8010 Graz, Austria
(HER2) and is given to breast cancer patients whose tumors overexpress HER2 [1]. The recent surge in highthroughput sequencing of cancer genomes is delivering cheaper and more accurate tumor genome information [2-5], and it can be anticipated that more predictive biomarkers will be identified and that patients will increasingly be treated by focusing on the genetic architecture of their particular tumor rather than on the tumor's location or histological features.

However, cancer genomes are unstable and prone to changes under selection pressures such as the application of therapies. Thus, molecularly targeted cancer therapies require serial monitoring of the tumor genome's makeup to ensure that a given therapy is still 'hitting the target' or to detect whether new predictive biomarkers are emerging. However, serial biopsies of metastatic lesions cannot usually be performed because of their invasive nature. Furthermore, they frequently yield only sparse quantities of cytological material and therefore provide only limited information about the genetic content of cells. In fact, the inability to obtain adequate material for serial monitoring of tumor genotypes has been a major barrier to translating laboratory findings into therapy.

Methods for rapid, cost-effective, and non-invasive monitoring of tumor genomes and for identification of potential biomarkers at various time points during a disease course are needed. To this end, circulating tumor cells (CTCs) and circulating tumor DNA (ctDNA) offer a unique opportunity for serially monitoring tumor genomes in a non-invasive manner. As CTCs and ctDNAs are potential surrogates for the tumor itself, they are often referred to as 'liquid biopsy' [6-10].

CTCs are shed into the bloodstream from primary and metastatic tumor deposits. First observed in 1869 by the Australian physician Thomas Ashworth [11], the potential value of CTCs was not realized until the end of the 1990s. An initial focus of research when it began in earnest in the early 1990s was the rare tumor cells found in the bone marrow at the time of diagnosis, long before metastasis was evident $[8,9]$. In contrast to CTCs (tumor cells in the circulation), these disseminated tumor cells may remain in a dormant state for many years at a site in the body, such as in the bone marrow, and may give rise to metastases years after complete resection of the primary tumor. For example, in patients with breast 
cancer, several studies suggested that the presence of disseminated tumor cells in bone marrow is associated with a poorer prognosis $[12,13]$. However, frequent bone marrow biopsies are not practical, and therefore interest has shifted to CTCs, which can be obtained by a simple blood collection.

In fact, the isolation and characterization of CTCs has tremendous potential for providing new biological insights into the pivotal steps in metastases. Clinical applications include the identification of prognostic, predictive, and pharmacokinetic biomarkers $[9,14,15]$ (Figure 1). Such 'real time' longitudinal monitoring of CTC-derived genotypes may provide a non-invasive approach to identifying drug-sensitivity- and resistanceassociated markers, guiding therapeutic decisions (Figure 1).

Although the isolation and analysis of CTC hold great promise for the early detection of invasive cancer and the management of advanced disease, technological hurdles such as finding them among millions of normal hematogenous cells have limited their broad clinical utility. Here we review recent developments in CTC capture and analysis tools, CTC monitoring strategies, and insights into their biology. In addition, we cover progress in ctDNA analysis, which may become a complementary or alternative liquid biopsy to CTCs.

\section{CTC selection methods}

A major hurdle in CTC analysis is that CTCs constitute as few as 1 cell per $1 \times 10^{9}$ normal blood cells in patients with metastatic cancer, and therefore it is difficult to identify and isolate them [9]. As a consequence, multiple CTC selection and capture approaches have been developed and recently extensively reviewed $[6,9,10$, 16,17]. We refer the reader to these references for a complete overview of CTC selection technologies. Here, we focus only on some of the more commonly used CTC selection methods and on some recent microfluidics technologies, which were not covered in the aforementioned reviews.

The simplest CTC selection method is probably sizebased membrane filters. Such filters enrich cells larger than a certain diameter based on the assumption that CTCs are larger than blood cells $[18,19]$. However, a recent study reported a considerable size overlap between CTCs and leukocytes [20], so that size-based filter systems probably miss a proportion of CTCs.

At present the most widespread CTC detector is the CellSearch system (Veridex). This is a semi-automated system that enriches for cells expressing epithelial-cell adhesion molecules (EpCAMs) but lacking the leukocytespecific molecule CD45. Cells are further immunostained with fluorescent-labeled anti-keratin antibodies identifying, among others, cytokeratin (CK)8, CK18, and CK19
$[14,21,22]$. Using the CellSearch system, CTCs were found in the peripheral blood of patients with all major carcinomas, but not in participants without malignant diseases [23]. With this system, baseline and follow-up CTC levels were reported to be strong predictors for progression-free and overall survival, which resulted in US Food and Drug Administration approval for monitoring patients with metastatic breast, prostate, and colorectal cancer [9].

To optimize the capture of CTCs, several microfluidic platforms have been developed (reviewed by Pratt et al. [24]). One is the CTC-chip, in which blood flows past EpCAM-coated microposts under precisely controlled laminar-flow conditions [15]. However, the difficulties in isolating these cells in this non-transparent three-dimensional array of microposts limited the options for subsequent single CTC analyses. Therefore, the same group developed this chip further, and instead of microposts the advanced chip uses surface ridges or herringbone grooves in the ceiling of the channel (it is thus dubbed the herringbone- or ${ }^{\mathrm{HB}} \mathrm{CTC}$-Chip). The grooves generate transverse flow, inducing microvortices, which direct cells toward the EpCAM-coated walls of the device $[25,26]$. Advantages include the use of transparent wells and less complex three-dimensional structures, facilitating analysis of captured cells.

Another microfluidic device for enhanced CTC capture is the micro-Hall detector, which detects the magnetic moments of cells in-flow after immunolabeling with magnetic nanoparticles. The detection of CTCs was achieved using a panel of immuno-magnetic nanoparticles against four markers, EpCAM, HER2/neu, epidermal growth factor receptor (EGFR), and mucin-1 (MUC1) [27].

However, devices depending on EpCAM for CTC capture have the drawback that they miss EpCAMnegative CTCs, such as cells that have undergone an epithelial-to-mesenchymal transition (EMT), a process thought to facilitate the dissemination of tumor cells into the surrounding tissue and circulation [28]. Furthermore, the heterogeneity of EpCAM expression on the surface of CTCs can cause variation in the ability to detect them [23]. In addition, EpCAM methods cannot detect nonepithelial cancers, such as sarcomas.

In part, these limitations can be addressed by using cocktails of antibodies or by negative filtration, which uses antibodies to remove blood cells from a sample and leaves behind tumor cells. A new, more sophisticated approach to distinguish epithelial from mesenchymal cancer cells used RNA in situ hybridization (RNA-ISH) to differentially stain cells according to the expression levels of epithelial and mesenchymal genes [29]. Another CTC capture platform, the CTC-iChip, is capable of isolating both $\mathrm{EpCAM}^{+}$and $\mathrm{EpCAM}^{-} \mathrm{CTCs}$ using a series of steps: debulking (cytoreduction to remove red blood 


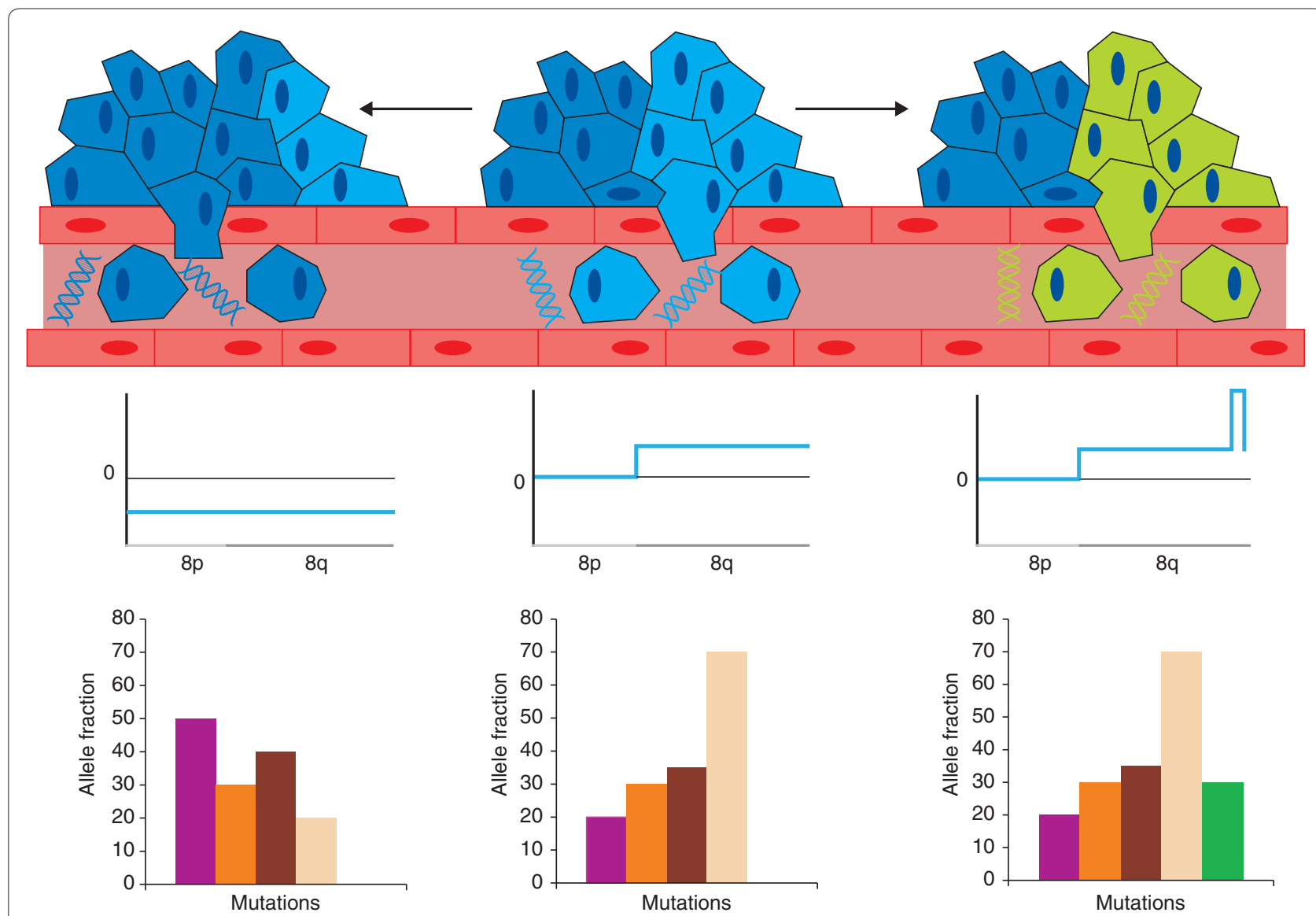

Figure 1. Monitoring of tumor genomes using CTCs and ctDNA. Cancer cells can disseminate from the primary site through the lymphatic system (not shown) or by hematogenous routes. In addition, tumor cells can release DNA into the circulation (illustrated as small DNA strands). The figure shows a tumor consisting of two clones, center, indicated in dark and light blue. In this example the light blue clone releases CTCs and DNA into the circulation at a given time. Analysis of CTCs and ctDNA can reveal tumor-specific copy number changes (chromosome 8 is included here as an example, and is depicted as an overrepresentation of the long arm) and mutations at the nucleotide level (illustrated as the allele fraction of mutations at the bottom). If the tumor genome is stable, repeated analyses would reveal no additional copy number changes or mutations. However, cells from one clone may decrease (left, the light blue clone) as a result of selection pressures associated with a given treatment, whereas cells from another (dark blue clone) increase so that CTCs and ctDNA from this clone may be preferentially released into the circulation. As the material in the circulation is now from a different clone, copy number changes (here illustrated as a loss of the entire chromosome 8) and the allele frequency of mutations may differ substantially from the previous analysis. Alternatively (right), the light blue clone could acquire a new mutation for example, with increased resistance to a given therapy (shown as green cells) - and because they evolved directly from the light blue cells, copy numbers and mutations will be very similar to the earlier analysis. However, new mutations may be detected (indicated here as a high level amplification on 8q and a new mutation).

cells, platelets, and plasma proteins, so that only nucleated cells, white blood cells, and CTCs are retained); inertial focusing (a microscale hydrodynamic phenomenon used to position or focus randomly distributed cells - for example, in a single central stream); and magnetic separation (separation of magnetically labeled cells from unlabeled cells). These steps allow strategies for CTC isolation that is either dependent on or independent of the tumor membrane epitope, making the CTC-iChip applicable to virtually all cancers, that is, to epithelial and non-epithelial cancers [20].

However, these new CTC microfluidic devices have not been validated to a comparable level as the CellSearch system with regard to their specificity, reproducibility, and clinical relevance so far, so it will be of interest to see which make it into the clinic. In any case, all separation strategies will probably miss some cancer cells, and a particular challenge will be to answer the question of whether the cells that are collected are the ones that can seed new tumors. To answer essential questions about CTC biology such as this, analysis tools as outlined below are needed.

\section{CTC analysis}

Currently the main clinical CTC application consists of enumeration of putative CTCs without further analyses. 
However, counting cells barely makes use of the potential information residing in CTCs and does not reflect how oncologists want to use CTCs. In general, there are various approaches to studying CTCs and to analyzing their protein, RNA, and DNA content $[9,10]$.

One protein-based analysis is the EPISPOT (EPithelial ImmunoSPOT) assay, which captures proteins secreted from CTCs during a 24 to 48 hour culture on a membrane coated with antibodies. This assay can distinguish between apoptotic and viable CTCs and has the potential to identify and differentiate between different proteins within CTCs (CTC protein fingerprinting) [6,30].

Another protein analysis approach uses quantitative immunofluorescence to simultaneously visualize differently labeled targets within CTCs. For example, Miyamoto et al. [31] first selected prostate cancer-specific candidate gene products for which reliable antibodies were available: prostate-specific antigen (PSA; KLK3) and prostate-specific membrane antigen (PSMA; FOLH1). They then used antibodies against PSA and PSMA to distinguish CTCs from men with prostate cancer with activated and inactivated androgen receptor (AR) signaling using a quantitative immunofluorescence assay (see below).

There are also various ways to study RNA expression in CTCs. As mentioned before, one method is the quantifiable, dual-colorimetric RNA-ISH assay developed by Yu et al. [29], which uses the expression of seven pooled epithelial and three mesenchymal transcripts. By direct visualization of the hybridization pattern within cells, CTCs with epithelial and mesenchymal composition could be identified. Alternatively, RNA can be extracted and sequenced. For example, Stott et al. [26] detected the prostate cancer-specific TMPRSS2-ERG fusion in RNA extracted from CTCs from patients with metastatic prostate cancer. Microfluidic-based single cell expression analysis was reported in individual CTCs. This highdimensional gene expression measurement allowed transcriptional profiling of 87 cancer-associated and reference genes on a cell-by-cell basis [32].

Recently it has also been shown that CTC lines can be developed and kept in long-term culture [33,34]. Such CTC lines can be used for further CTC characterization and to investigate functional CTC properties, such as invasiveness or preferential sites for metastases when xenografted into nude mice.

The cytogenetic composition of CTCs can be assessed with interphase fluorescence in situ hybridization (FISH) $[35,36]$. However, interphase FISH allows assessment of the copy number changes only for genomic regions covered by the FISH probes. On a genome-wide level, copy number changes of the CTC genome can be studied after whole genome amplification (WGA) by arraycomparative genomic hybridization (array-CGH) either of single CTCs [37] or by pooling several CTCs [38,39] (Figure 2).

Several recent studies have suggested that highresolution single-cell DNA sequencing is feasible [37,4045]. However, all of these strategies depend on an initial WGA step, because a single diploid cell contains only $6.6 \mathrm{pg}$ of DNA, whereas micrograms of DNA are required for sequencing (Figure 2). As a consequence, single-cell sequencing is prone to artifacts, which may be introduced during either amplification or sequencing. We have recently published the first study that analyzed genomewide copy number changes and mutations in a panel of genes by next-generation sequencing (NGS) in single CTCs [37]. In our previous papers we explained why single-cell CTC sequencing differs from sequencing of other single cells $[37,46]$. First, somatic mutations in tumor cells include many changes at the nucleotide level and copy number of DNA segments [4]. However, the reliable and simultaneous detection of both copy number changes and mutations at the nucleotide level cannot be achieved by most recently published single-cell approaches [40,42-44]. A recent amplification method reported the genome-wide detection of single-nucleotide and copy number variations in single human cells $[41,45]$. This new WGA method, 'multiple annealing and looping-based amplification cycles' (MALBAC), uses five initial quasilinear pre-amplification cycles, which are intended to reduce the bias often observed with nonlinear amplification. This is then followed by exponential amplification cycles. However, this new method has not yet been applied to CTCs, so it remains unclear whether it can be combined with any of the CTC capture procedures. Second, as CTCs are extremely rare, usually only a very limited number of cells are available for analysis. Hence, strategies such as calling mutations only if they are observed in a specified number of cells, which have been used by some single cell sequencing approaches [40,44], are not applicable to CTCs. Third, isolation of CTCs from millions of normal cells is a much more complex procedure than isolation of cells from a primary tumor or from another cell population. Fourth, no suitable material for comparison of CTC results is available. This is because CTCs may recur years after initial diagnosis of the primary tumor and may have acquired multiple, new changes since then. Fifth, CTCs may be released from various metastatic sites and their origin cannot usually be traced. Finally, CTCs have been reported to be heterogeneous [47-49] and may therefore show tremendous cell-to-cell variability.

Nevertheless, the importance of a molecular characterization of CTCs is highlighted by the fact that in our study [37] the CellSearch system selected epithelial and CD45-negative cells, in which we did not find tumorspecific mutations previously identified in the respective 


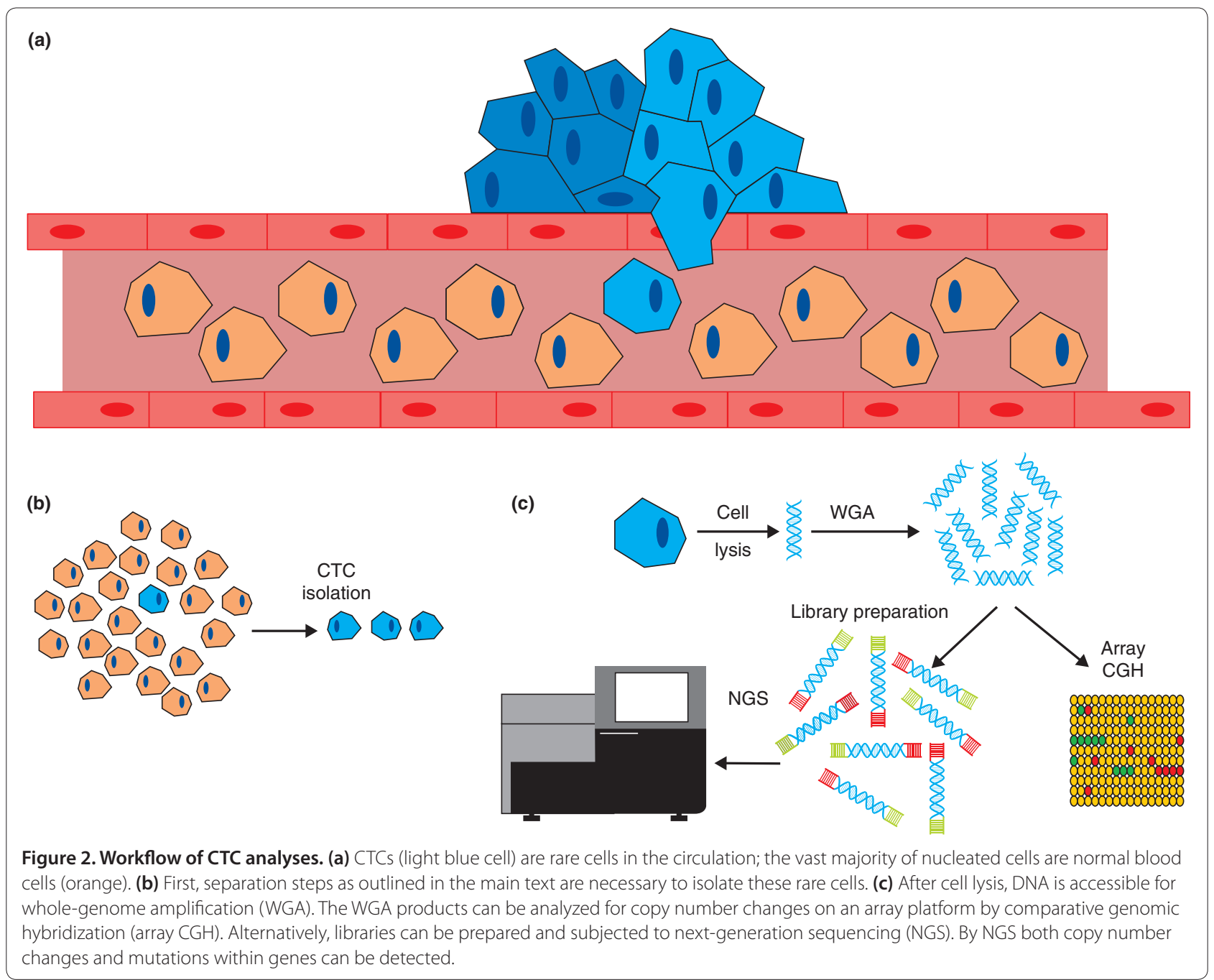

primary tumors and which had each a balanced copy number profile. Instead of CTCs these cells could be circulating epithelial cells, which had recently been described in patients with benign colon diseases [50]. Thus, it is possible that not all epithelial, CD45-negative cells are CTCs.

\section{Disease monitoring with CTCs}

One of the most attractive goals of CTC analysis is disease monitoring. Indeed, even the presence of CTCs in peripheral blood is a prognostic biomarker and can be measured to track therapeutic response in patients with cancer [14,21,23,51-53]. However, monitoring has gone far beyond simple CTC counting. As cancer can develop resistance against a given therapy and may then recur or spread, the timely identification of secondary mutations is of utmost importance, so that patients who are unlikely to benefit from continuing the initial therapy are spared the side effects and the loss of time that could have been spent in pursuing more active agents.
For example, patients with non-small-cell lung cancer and somatic activating mutations in the EGFR gene are likely to benefit from treatment with selective EGFR kinase inhibitors. However, secondary EGFR mutations that inhibit the binding of tyrosine inhibitors and cause resistance to such drugs may emerge [54]. Using the CTC-chip, CTCs from patients with metastatic nonsmall-cell lung cancer were subjected to serial EGFR mutation analysis. Indeed, by monitoring CTCs the acquisition of the recurrent T790M-EGFR drug resistance mutation became evident and coincided with the development of clinically refractory disease [55].

In contrast to this approach, which focused on mutation analysis for a specific, previously known resistance marker [55], genome-wide analysis strategies should, in theory, capture all possible mechanisms of resistance. For example, the results of our CTC analyses using arrayCGH and NGS [37] suggested that we can indeed elucidate relevant changes in the tumor genome that had either not been present or not been observed at the time 
of initial diagnosis. Analysis of the genomes of the primary tumor and metastasis of one of our patients did not reveal changes that would have made her eligible for enrolment in a trial with a CDK inhibitor such as alvocidib. Yet the CTCs obtained 34 and 24 months after diagnosis of the primary tumor and liver metastasis, respectively, revealed a high level of amplification of $C D K 8$, which had not been noted in the previous analyses [37]. Therefore, this amplification may be a viable target for CDK inhibitors, which are currently in clinical trials [56-58].

Miyamoto et al. [31] used the ${ }^{\mathrm{HB}}$ CTC-Chip and analyzed CTCs with the aforementioned PSA and PSMA quantitative immunofluorescence assay. PSA is upregulated following androgen receptor (AR) activation and PSMA is upregulated following $\mathrm{AR}$ suppression, so that $\mathrm{PSA}^{+}$ PSMA- CTCs indicate activated AR whereas CTCs with a reverse pattern, PSA- $\mathrm{PSMA}^{+}$, indicate suppressed AR. In untreated patients, single-CTC immunofluorescence analysis revealed predominantly the expected $\mathrm{PSA}^{+}$ $\mathrm{PSMA}^{-}$signatures. Initiation of first-line androgen deprivation therapy switched this pattern to PSA- $\mathrm{PSMA}^{+}$. The presence of a mixed $\mathrm{PSA}^{+} \mathrm{PSMA}^{+}$pattern or CTCs with $\mathrm{PSA}^{+} \mathrm{PSMA}^{-}$despite treatment was associated with an adverse treatment outcome. These data suggested that CTCs may help to guide therapy in prostate cancer [31].

In summary, CTC characterization might be a useful biomarker for treatment response and for monitoring changes in tumor genomes.

\section{CTC biology}

The other current area of CTC research addresses their biology to learn more about the process of metastasis [7]. The mechanisms that implicate CTCs in metastatic disease remain elusive, and a particular challenge is to answer the question of whether the cells that are collected with the aforementioned approaches have the potential to seed new tumors. To this end, mouse models are instrumental [59]. For example, mouse models revealed that metastasis is not a unidirectional process but a multidirectional one in which cancer cells do not seed only distant sites, but also the primary tumor itself. This latter process has been termed 'self-seeding' [60,61].

It has been hypothesized that CTCs include putative precursors that initiate distal metastases. However, the existence and phenotype of such putative metastasisinitiating cells remains elusive.

Using an endogenous mouse pancreatic cancer model, single-molecule RNA sequencing from CTCs identified enriched expression of Wnt2. Indeed, expression of WNT2 in human pancreatic cancer cells was shown to increase metastatic propensity in vivo [62]. Another study used a xenograft assay to demonstrate that primary human luminal breast cancer CTCs contain cells that give rise to metastases in mice in various organs. These metastasis-competent CTC populations expressed EpCAM, CD44, CD47, and MET, and in a small cohort of patients with metastases it could be shown that the presence of CTCs with such an expression profile was correlated with lower overall survival and increased number of metastatic sites [63]. Thus, mouse models contribute to the identification of functional circulating metastasis-competent CTCs, and their molecular analysis has great potential to identify candidate therapeutic targets to prevent the distal spread of cancer.

Another exciting topic is the role of EMT in tumor metastasis. Yu et al. [29] measured the expression of mesenchymal and epithelial markers in CTCs from breast cancer patients. Serial CTC monitoring suggested an association of mesenchymal CTCs with disease progression. In one patient, reversible shifts between mesenchymal and epithelial cell fates were associated with response to therapy and disease progression [29]. Another recent study focused specifically on EpCAMCTCs [33]. In patients with breast cancer, cell identification was then based on protein detection by immunofluorescence or FISH to detect CTCs overexpressing EGFR, HPSE, a potent tumorigenic, angiogenic, and prometastatic molecule, and ALDH1, a tumor-initiating stem cell marker. The authors [29] also developed CTC lines from some of these patients and identified a potential expression signature of brain metastasis, which was, in addition to the overexpressed EGFR and HPSE, characterized by high expression of HER2 and Notch1 [33].

In summary, studying CTC biology has the potential to elucidate the role of EMT and to discover processes instrumental for metastasis.

\section{ctDNA as an alternative to CTC analysis}

In addition to progress in CTC research, significant advancement has also been made with ctDNA. The presence of small amounts of tumor DNA in the plasma of cancer patients was demonstrated several decades ago [64-67]. Since then, multiple studies have investigated plasma DNA's potential as a biomarker (for a detailed review see [68]). Initially the focus was on the identification of known alterations previously found in the resected tumors from the same patients in plasma DNA for monitoring purposes [69-75]. Given that chromosomal copy number changes occur frequently in human cancer, approaches allowing the mapping of tumorspecific copy number changes from plasma DNA using array-CGH [76] or NGS of plasma DNA [77-81] had been developed. Recent studies have also demonstrated the simultaneous detection of genome-wide copy number changes and mutations at the nucleotide level $[77,78,80]$. The usual workflow for processing of ctDNA is illustrated 


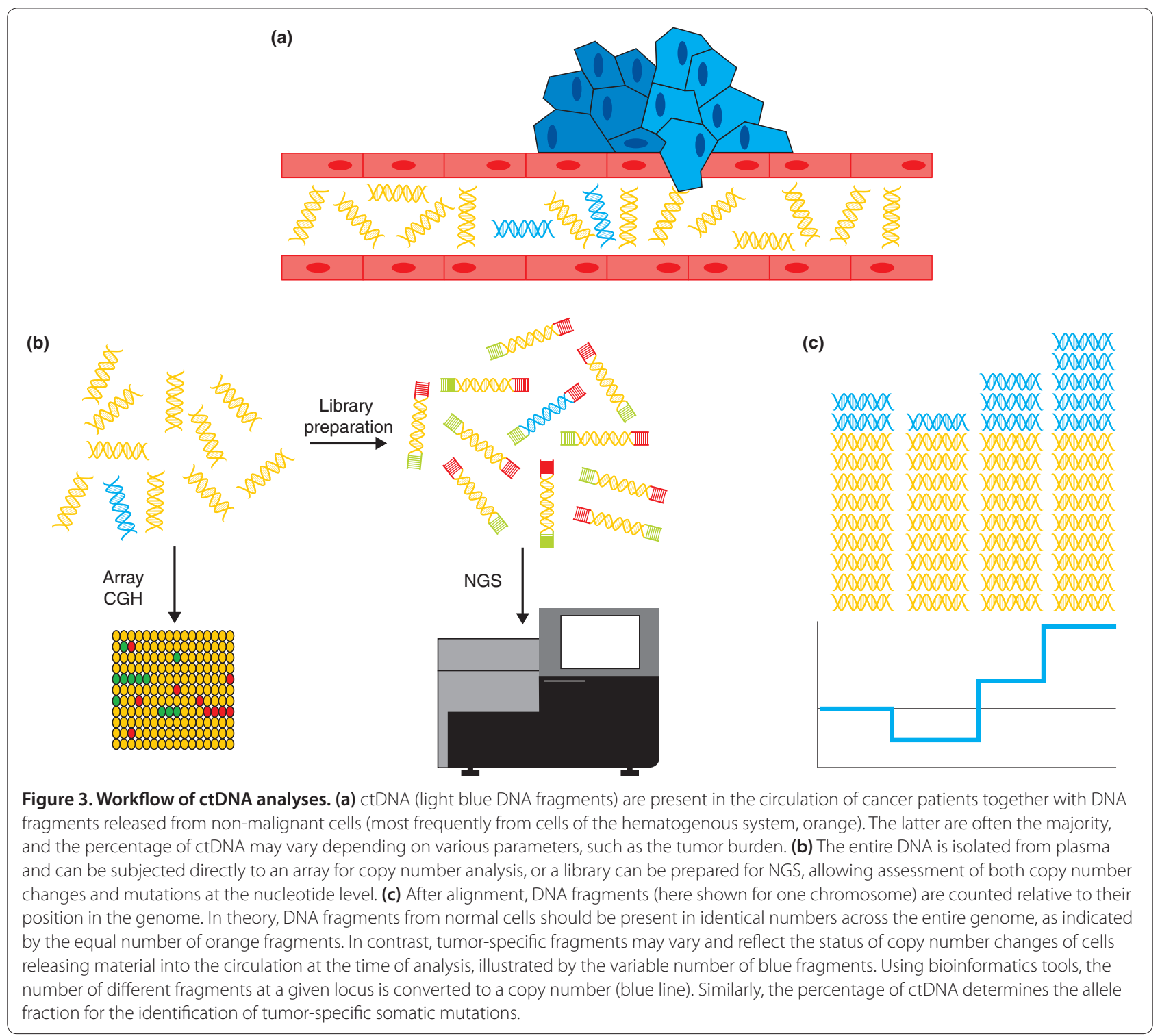

in Figure 3. Importantly, ctDNA does not depend on special equipment, unlike CTC capture. Instead, ctDNA is analyzed together with plasma DNA from normal cells, which is always present in the circulation (Figure 3). Current NGS technologies are sensitive enough to detect tumor-specific somatic mutations, even if the ctDNA fragments represent only a minority of all DNA fragments in the circulation. Furthermore, ctDNA analyses are independent of EpCAM markers, unlike most CTC capturing systems. On the other hand, CTCs yield information on a cellular level and thus clonality, whereas ctDNA reflects an average of all tumor cells releasing DNA into the circulation. Despite these differences, CTC and ctDNA analyses may reveal surprisingly congruent results. For example, Figure 4 depicts array-CGH analyses from a CTC and plasma DNA from the same patient with colon cancer from our previous studies [37,76]. Differences between CTC and plasma DNA or ctDNA analyses are summarized in Table 1.

So far, recent ctDNA publications have focused on cancer patients with very advanced diseases and therefore very high concentrations of ctDNA [69,70,74,76-82]. Detailed experiences with early stage cancer and low concentrations of ctDNA are lacking. Furthermore, normal DNA always dilutes the ctDNA (Figure 3), which may be aggravated during inflammation and injury when very high amounts of normal DNA are released into the circulation. However, receiver operating characteristic analyses suggested that even tumor DNA concentrations at very low levels should be detectable in the circulation of patients with cancer [78,79]. If this can be verified in appropriate clinical studies, ctDNA appears to be 

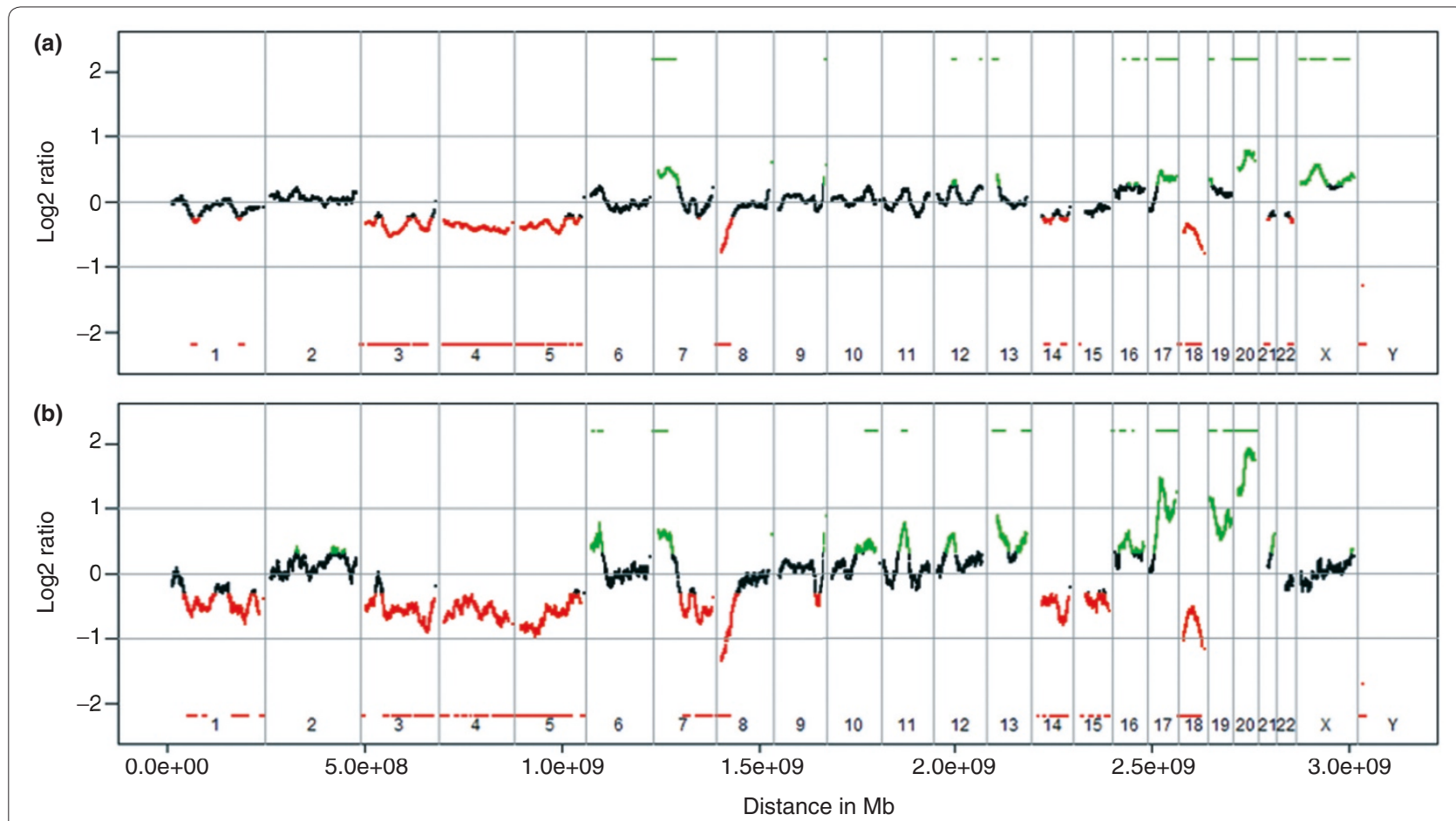

Figure 4. Analysis of ctDNA and CTC from a patient with colon cancer using array-CGH $[37,76]$. Green indicates overrepresented, red underrepresented and black balanced regions. (a) Plasma DNA ratio profile demonstrates losses on chromosomes 3, 4, 5, 8p, and 18 and gains on chromosomes 7p, 17q, and 20. (b) The CTC had almost identical copy number changes with those observed with the plasma DNA.

Table 1. Differences between CTC and ctDNA analyses

\begin{tabular}{lll}
\hline & CTC & ctDNA \\
\hline Equipment & Special instrumentation for cell identification needed & None, simple blood collection \\
Isolation of CTC or ctDNA & $\begin{array}{l}\text { Complex CTC isolation out of thousands of cells and } \\
\text { complex single-cell transfer for further processing }\end{array}$ & $\begin{array}{l}\text { No isolation of ctDNA required; instead, standard } \\
\text { preparation of plasma DNA }\end{array}$ \\
$\begin{array}{ll}\text { WGA required for DNA analysis } \\
\text { Information on heterogeneity }\end{array}$ & $\begin{array}{l}\text { Yes, if enough CTCs are captured and successfully } \\
\text { and clonality }\end{array}$ & No, results represent an average from all cells shedding \\
analyzed & Yes, for most CTC capture systems, such as the & Independent of any marker \\
& $\begin{array}{l}\text { CellSearch system. EpCAM-independent CTC capture } \\
\text { systems exist but await validation in clinical studies }\end{array}$ & \\
Applicability for basic metastasis & Instrumental, as it enables cell-by-cell analyses, & \\
research & generation of cell lines and analyses in animal models & Provides only a snapshot of the current status of the \\
Applicability for diagnostic or & tumor genome \\
monitoring purposes & Established for CTC enumeration; advancements & Appears to be very attractive because of the simplicity of \\
& will depend on improvements in CTC capturing, & obtaining plasma DNA; needs to be determined in \\
& analysis tools and associated costs & clinical studies
\end{tabular}

attractive as a diagnostic tool because of the ease with which it can be obtained. In contrast, CTCs may in addition provide more insights into tumor biology (Table 1). However, the sensitivity of CTC versus plasma DNA as predictive and prognostic biomarkers still needs to be explored in detail in future studies.

\section{Conclusions and future perspectives}

Both CTCs and ctDNA provide snapshots of genomic alterations in primary tumors and metastases at various stages during the course of disease. Recent years have witnessed tremendous progress in the identification, capturing, and analysis of CTCs. The advantages of CTC analyses include that - provided they were selected with highly specific approaches as discussed above - they represent a pure tumor cell population. Together with new WGA approaches and NGS, these analyses mean that unique insights into clonal heterogeneity and evolution at various disease stages can be obtained. CTCs provide new options to study metastasis and to monitor 
the evolution of tumor genomes with high resolution. As CTCs are very rare cells, capturing them depends on rather sophisticated equipment, which is a limitation. In contrast, plasma DNA is easily obtained; however, tumor DNA fragments are diluted with various amounts of DNA from normal cells, which may hamper analysis.

Most CTC and ctDNA studies were done with patients with metastatic disease. At present, there are not enough data available to judge whether these CTC and ctDNA analyses are sensitive enough to detect a person's initial tumor early in its development. Furthermore, it is unknown whether they are suitable for screening purposes in individuals with an increased risk of developing a tumor.

However, despite the remarkable progress in recent years, several challenges remain. Better CTC detectors recognizing both $\mathrm{EpCAM}^{+}$and $\mathrm{EpCAM}^{-}$cells at high speed with confidence are needed for clinical use. A current problem of all CTC detectors is the secure and automated transfer of single CTCs for further processing. At present, this is usually done by manual micromanipulation approaches, which require expertise and skilled personnel and which can be time consuming. This may change in the near future, as automated cell sorting and recovery devices are becoming available. For example, the DepArray system uses a non-uniform electric field, which can be used to move cells and to eventually recover cell populations in an automated way. First reports describing the isolation of a pure CTC population with this device and their subsequent comprehensive analyses were indeed promising $[83,84]$.

Furthermore, technologies isolating sufficient numbers of living CTCs, which can be expanded in culture or directly used for functional studies, are needed. To this end, appropriate culturing conditions for both epithelial and mesenchymal CTCs need to be established. An important question is whether the cells we are capturing are the seeds for new tumors. To this end, the involvement of the EMT process or of stem cell markers in CTCs needs to be further elucidated. If the details of these cells reveal how human cancers spread, they may offer new treatment options for stopping it at an early stage. At present, the characterization of the phenotype of metastasis-initiating cells among CTCs is still in its early infancy [63]. Identification of such precursors may identify cellular pathways contributing to both the bloodborne dissemination of cancer and processes involved in metastatic colonization.

The technologies we describe here represent fundamental steps towards the identification of predictive and prognostic biomarkers. There is no doubt that they will evolve to new non-invasive diagnostic tests that are amenable to routine clinical use in terms of sensitivity and cost. Accordingly, they will change the management of patients with cancer as they will allow the non-invasive monitoring of tumor genomes, which presents another step towards personalized medicine.

\section{Competing interests}

The authors declare that they have no competing interests.

\section{Abbreviations}

$A R$, androgen receptor; CTC, circulating tumor cell; ctDNA, circulating tumor DNA; EGFR, epidermal growth factor receptor; EMT, epithelial-to-mesenchymal transition; EpCAM, epithelial cell adhesion molecule; FISH, fluorescence in situ hybridization; HER2, human epidermal growth factor receptor 2; ISH, in situ hybridization; NGS, next-generation sequencing; PSA, prostate-specific antigen; PSMA, prostate-specific membrane antigen; WGA, whole-genome amplification.

\section{Acknowledgements}

We thank Maria Langer-Winter for editing the manuscript. Funding in our laboratory was provided by the Austrian Science Fund (FWF) (grant numbers P20338, P23284 and W 1226-B18, DKplus Metabolic and Cardiovascular Disease), and the Oesterreichische Nationalbank (15093).

\section{Published: 23 August 2013}

\section{References}

1. Spector NL, Blackwell KL: Understanding the mechanisms behind trastuzumab therapy for human epidermal growth factor receptor 2-positive breast cancer. J Clin Oncol 2009, 27:5838-5847.

2. McLeod HL: Cancer pharmacogenomics: early promise, but concerted effort needed. Science 2013, 339:1563-1566.

3. Dancey JE, Bedard PL, Onetto N, Hudson TJ: The genetic basis for cancer treatment decisions. Cell 2012, 148:409-420.

4. Stratton MR: Exploring the genomes of cancer cells: progress and promise. Science 2011, 331:1553-1558.

5. Vogelstein B, Papadopoulos N, Velculescu VE, Zhou S, Diaz LA Jr, Kinzler KW: Cancer genome landscapes. Science 2013, 339:1546-1558.

6. Alix-Panabieres C, Pantel K: Circulating tumor cells: liquid biopsy of cancer. Clin Chem 2013, 59:110-118.

7. Maheswaran S, Haber DA: Circulating tumor cells: a window into cancer biology and metastasis. Curr Opin Genet Dev 2010, 20:96-99.

8. Pantel K, Brakenhoff RH: Dissecting the metastatic cascade. Nat Rev Cancer 2004, 4:448-456.

9. Pantel K, Brakenhoff RH, Brandt B: Detection, clinical relevance and specific biological properties of disseminating tumour cells. Nat Rev Cancer 2008, 8:329-340

10. Yu M, Stott S, Toner M, Maheswaran S, Haber DA: Circulating tumor cells: approaches to isolation and characterization. J Cell Biol 2011, 192:373-382.

11. Ashworth TR: A case of cancer in which cells similar to those in the tumors were seen in the blood after death. Aus Med J 1869, 14:146-147.

12. Braun S, Pantel K, Muller P, Janni W, Hepp F, Kentenich CR, Gastroph S, Wischnik A, Dimpfl T, Kindermann G, Riethmuller G, Schlimok G: Cytokeratinpositive cells in the bone marrow and survival of patients with stage I, II, or III breast cancer. N Engl J Med 2000, 342:525-533.

13. Braun S, Vogl FD, Naume B, Janni W, Osborne MP, Coombes RC, Schlimok G, Diel IJ, Gerber B, Gebauer G, Pierga JY, Marth C, Oruzio D, Wiedswang G, Solomayer EF, Kundt G, Strobl B, Fehm T, Wong GY, Bliss J, Vincent-Salomon A, Pantel K: A pooled analysis of bone marrow micrometastasis in breast cancer. N Engl J Med 2005, 353:793-802.

14. Cristofanilli M, Budd GT, Ellis MJ, Stopeck A, Matera J, Miller MC, Reuben JM, Doyle GV, Allard WJ, Terstappen LW, Hayes DF: Circulating tumor cells, disease progression, and survival in metastatic breast cancer. N Engl J Med 2004, 351:781-791

15. Nagrath S, Sequist LV, Maheswaran S, Bell DW, Irimia D, Ulkus L, Smith MR, Kwak EL, Digumarthy S, Muzikansky A, Ryan P, Balis UJ, Tompkins RG, Haber DA, Toner M: Isolation of rare circulating tumour cells in cancer patients by microchip technology. Nature 2007, 450:1235-1239.

16. Lianidou ES, Markou A: Circulating tumor cells in breast cancer: detection systems, molecular characterization, and future challenges. Clin Chem 2011, 57:1242-1255.

17. Joosse SA, Pantel K: Biologic challenges in the detection of circulating tumor cells. Cancer Res 2013, 73:8-11. 
18. Lin HK, Zheng S, Williams AJ, Balic M, Groshen S, Scher HI, Fleisher M, Stadler W, Datar RH, Tai YC, Cote RJ: Portable filter-based microdevice for detection and characterization of circulating tumor cells. Clin Cancer Res 2010, 16:5011-5018

19. Paterlini-Brechot $P$, Benali NL: Circulating tumor cells (CTC) detection: clinical impact and future directions. Cancer Lett 2007, 253:180-204.

20. Ozkumur E, Shah AM, Ciciliano JC, Emmink BL, Miyamoto DT, Brachtel E, Yu M, Chen PI, Morgan B, Trautwein J, Kimura A, Sengupta S, Stott SL, Karabacak NM, Barber TA, Walsh JR, Smith K, Spuhler PS, Sullivan JP, Lee RJ, Ting DT, Luo X, Shaw AT, Bardia A, Sequist LV, Louis DN, Maheswaran S, Kapur R, Haber DA, Toner M: Inertial focusing for tumor antigen-dependent and -independent sorting of rare circulating tumor cells. Sci Trans/Med 2013, 5:179ra147.

21. Cristofanilli M, Hayes DF, Budd GT, Ellis MJ, Stopeck A, Reuben JM, Doyle GV, Matera J, Allard WJ, Miller MC, Fritsche HA, Hortobagyi GN, Terstappen LW: Circulating tumor cells: a novel prognostic factor for newly diagnosed metastatic breast cancer. J Clin Oncol 2005, 23:1420-1430.

22. Riethdorf S, Fritsche H, Muller V, Rau T, Schindlbeck C, Rack B, Janni W, Coith C, Beck K, Janicke F, Jackson S, Gornet T, Cristofanilli M, Pantel K: Detection of circulating tumor cells in peripheral blood of patients with metastatic breast cancer: a validation study of the CellSearch system. Clin Cancer Res 2007, 13:920-928.

23. Allard WJ, Matera J, Miller MC, Repollet M, Connelly MC, Rao C, Tibbe AG, Uhr JW, Terstappen LW: Tumor cells circulate in the peripheral blood of all major carcinomas but not in healthy subjects or patients with nonmalignant diseases. Clin Cancer Res 2004, 10:6897-6904.

24. Pratt ED, Huang C, Hawkins BG, Gleghorn JP, Kirby BJ: Rare cell capture in microfluidic devices. Chem Eng Sci 2011, 66:1508-1522.

25. Stott SL, Hsu CH, Tsukrov DI, Yu M, Miyamoto DT, Waltman BA, Rothenberg SM, Shah AM, Smas ME, Korir GK, Floyd FP Jr, Gilman AJ, Lord JB, Winokur D, Springer S, Irimia D, Nagrath S, Sequist LV, Lee RJ, Isselbacher KJ, Maheswaran S, Haber DA, Toner M: Isolation of circulating tumor cells using a microvortex-generating herringbone-chip. Proc Natl Acad Sci U S A 2010, 107:18392-18397.

26. Stott SL, Lee RJ, Nagrath S, Yu M, Miyamoto DT, Ulkus L, Inserra EJ, Ulman M, Springer S, Nakamura Z, Moore AL, Tsukrov DI, Kempner ME, Dahl DM, Wu CL, lafrate AJ, Smith MR, Tompkins RG, Sequist LV, Toner M, Haber DA, Maheswaran S: Isolation and characterization of circulating tumor cells from patients with localized and metastatic prostate cancer. Sci Trans/ Med 2010, 2:25ra23.

27. Issadore D, Chung J, Shao H, Liong M, Ghazani AA, Castro CM, Weissleder R, Lee $\mathrm{H}$ : Ultrasensitive clinical enumeration of rare cells ex vivo using a micro-hall detector. Sci Trans/ Med 2012, 4:141 ra192.

28. Scheel C, Weinberg RA: Cancer stem cells and epithelial-mesenchymal transition: concepts and molecular links. Semin Cancer Bio/ 2012. 22:396-403.

29. Yu M, Bardia A, Wittner BS, Stott SL, Smas ME, Ting DT, Isakoff SJ, Ciciliano JC, Wells MN, Shah AM, Concannon KF, Donaldson MC, Sequist LV, Brachtel E, Sgroi D, Baselga J, Ramaswamy S, Toner M, Haber DA, Maheswaran S: Circulating breast tumor cells exhibit dynamic changes in epithelial and mesenchymal composition. Science 2013, 339:580-584

30. Alix-Panabieres C: EPISPOT assay: detection of viable DTCs/CTCs in solid tumor patients. Recent Results Cancer Res 2012, 195:69-76

31. Miyamoto DT, Lee RJ, Stott SL, Ting DT, Wittner BS, Ulman M, Smas ME, Lord JB, Brannigan BW, Trautwein J, Bander NH, Wu CL, Sequist LV, Smith MR, Ramaswamy S, Toner M, Maheswaran S, Haber DA: Androgen receptor signaling in circulating tumor cells as a marker of hormonally responsive prostate cancer. Cancer Discov 2012, 2:995-1003.

32. Powell AA, Talasaz AH, Zhang H, Coram MA, Reddy A, Deng G, Telli ML, Advani $\mathrm{RH}$, Carlson RW, Mollick JA, Sheth S, Kurian AW, Ford JM, Stockdale FE, Quake SR, Pease RF, Mindrinos MN, Bhanot G, Dairkee SH, Davis RW, Jeffrey SS: Single cell profiling of circulating tumor cells: transcriptional heterogeneity and diversity from breast cancer cell lines. PloS One 2012, 7:e33788

33. Zhang L, Ridgway LD, Wetzel MD, Ngo J, Yin W, Kumar D, Goodman JC, Groves MD, Marchetti D: The identification and characterization of breast cancer CTCs competent for brain metastasis. Sci Trans/Med 2013, 5:180ra148.

34. Ameri K, Luong R, Zhang H, Powell AA, Montgomery KD, Espinosa I, Bouley DM, Harris AL, Jeffrey SS: Circulating tumour cells demonstrate an altered response to hypoxia and an aggressive phenotype. Br J Cancer 2010, 102:561-569.
35. Attard G, Swennenhuis JF, Olmos D, Reid AH, Vickers E, A'Hern R, Levink R, Coumans F, Moreira J, Riisnaes R, Oommen NB, Hawche G, Jameson C Thompson E, Sipkema R, Carden CP, Parker C, Dearnaley D, Kaye SB, Cooper CS, Molina A, Cox ME, Terstappen LW, de Bono JS: Characterization of ERG, AR and PTEN gene status in circulating tumor cells from patients with castration-resistant prostate cancer. Cancer Res 2009, 69:2912-2918.

36. Flores LM, Kindelberger DW, Ligon AH, Capelletti M, Fiorentino M, Loda M, Cibas ES, Janne PA, Krop IE: Improving the yield of circulating tumour cells facilitates molecular characterisation and recognition of discordant HER2 amplification in breast cancer. Br J Cancer 2010, 102:1495-1502.

37. Heitzer E, Auer M, Gasch C, Pichler M, Ulz P, Hoffmann EM, Lax S, WaldispuehlGeigl J, Mauermann O, Lackner C, Hofler G, Eisner F, Sill H, Samonigg H, Pantel K, Riethdorf S, Bauernhofer T, Geigl JB, Speicher MR: Complex tumor genomes inferred from single circulating tumor cells by array-CGH and next-generation sequencing. Cancer Res 2013, 73:2965-2975.

38. Magbanua MJ, Sosa EV, Roy R, Eisenbud LE, Scott JH, Olshen A, Pinkel D, Rugo HS, Park JW: Genomic profiling of isolated circulating tumor cells from metastatic breast cancer patients. Cancer Res 2013, 73:30-40.

39. Magbanua MJ, Sosa EV, Scott JH, Simko J, Collins C, Pinkel D, Ryan CJ, Park JW: Isolation and genomic analysis of circulating tumor cells from castration resistant metastatic prostate cancer. BMC Cancer 2012, 12:78.

40. Hou Y, Song L, Zhu P, Zhang B, Tao Y, Xu X, Li F, Wu K, Liang J, Shao D, Wu H, Ye X, Ye C, Wu R, Jian M, Chen Y, Xie W, Zhang R, Chen L, Liu X, Yao X, Zheng H, Yu C, Li Q, Gong Z, Mao M, Yang X, Yang L, Li J, Wang W, et al.: Single-cell exome sequencing and monoclonal evolution of a JAK2-negative myeloproliferative neoplasm. Cell 2012, 148:873-885.

41. Lu S, Zong C, Fan W, Yang M, Li J, Chapman AR, Zhu P, Hu X, Xu L, Yan L, Bai F, Qiao J, Tang F, Li R, Xie XS: Probing meiotic recombination and aneuploidy of single sperm cells by whole-genome sequencing. Science 2012, 338:1627-1630.

42. Navin N, Kendall J, Troge J, Andrews P, Rodgers L, Mclndoo J, Cook K, Stepansky A, Levy D, Esposito D, Muthuswamy L, Krasnitz A, McCombie WR, Hicks J, Wigler M: Tumour evolution inferred by single-cell sequencing. Nature 2011, 472:90-94.

43. Wang J, Fan HC, Behr B, Quake SR: Genome-wide single-cell analysis of recombination activity and de novo mutation rates in human sperm. Cell 2012, 150:402-412.

44. Xu X, Hou Y, Yin X, Bao L, Tang A, Song L, Li F, Tsang S, Wu K, Wu H, He W, Zeng L, Xing M, Wu R, Jiang H, Liu X, Cao D, Guo G, Hu X, Gui Y, Li Z, Xie W, Sun X, Shi M, Cai Z, Wang B, Zhong M, Li J, Lu Z, Gu N, et al:: Single-cell exome sequencing reveals single-nucleotide mutation characteristics of a kidney tumor. Cell 2012, 148:886-895.

45. Zong C, Lu S, Chapman AR, Xie XS: Genome-wide detection of singlenucleotide and copy-number variations of a single human cell. Science 2012, 338:1622-1626

46. Auer M, Heitzer E, Ulz P, Geigl JB, Speicher MR: Single circulating tumor cell sequencing for monitoring. Oncotarget 2013, 4:812-813.

47. Gangnus R, Langer S, Breit E, Pantel K, Speicher MR: Genomic profiling of viable and proliferative micrometastatic cells from early-stage breast cancer patients. Clin Cancer Res 2004, 10:3457-3464.

48. Kraus J, Pantel K, Pinkel D, Albertson DG, Speicher MR: High-resolution genomic profiling of occult micrometastatic tumor cells. Genes Chromosomes Cancer 2003, 36:159-166.

49. Solakoglu O, Maierhofer C, Lahr G, Breit E, Scheunemann P, Heumos I, Pichlmeier U, Schlimok G, Oberneder R, Kollermann MW, Kollermann J, Speicher MR, Pantel K: Heterogeneous proliferative potential of occult metastatic cells in bone marrow of patients with solid epithelial tumors. Proc Natl Acad Sci U S A 2002, 99:2246-2251.

50. Pantel K, Deneve E, Nocca D, Coffy A, Vendrell JP, Maudelonde T, Riethdorf S, Alix-Panabieres C: Circulating epithelial cells in patients with benign colon diseases. Clin Chem 2012, 58:936-940.

51. Danila DC, Fleisher M, Scher HI: Circulating tumor cells as biomarkers in prostate cancer. Clin Cancer Res 2011, 17:3903-3912.

52. de Bono JS, Scher HI, Montgomery RB, Parker C, Miller MC, Tissing H, Doyle GV, Terstappen LW, Pienta KJ, Raghavan D: Circulating tumor cells predict survival benefit from treatment in metastatic castration-resistant prostate cancer. Clin Cancer Res 2008, 14:6302-6309.

53. Olmos D, Arkenau HT, Ang JE, Ledaki I, Attard G, Carden CP, Reid AH, A'Hern R, Fong PC, Oomen NB, Molife R, Dearnaley D, Parker C, Terstappen LW, de Bono JS: Circulating tumour cell (CTC) counts as intermediate end points in castration-resistant prostate cancer (CRPC): a single-centre experience. 
Ann Oncol 2009, 20:27-33.

54. Kobayashi S, Boggon TJ, Dayaram T, Janne PA, Kocher O, Meyerson M, Johnson BE, Eck MJ, Tenen DG, Halmos B: EGFR mutation and resistance of non-small-cell lung cancer to gefitinib. N Engl J Med 2005, 352:786-792.

55. Maheswaran S, Sequist LV, Nagrath S, Ulkus L, Brannigan B, Collura CV, Inserra E, Diederichs S, lafrate AJ, Bell DW, Digumarthy S, Muzikansky A, Irimia D, Settleman J, Tompkins RG, Lynch TJ, Toner M, Haber DA: Detection of mutations in EGFR in circulating lung-cancer cells. N Engl J Med 2008, 359:366-377.

56. Dickson MA, Shah MA, Rathkopf D, Tse A, Carvajal RD, Wu N, Lefkowitz RA, Gonen M, Cane LM, Dials HJ, Schwartz GK: A phase I clinical trial of FOLFIR in combination with the pan-cyclin-dependent kinase (CDK) inhibitor flavopiridol. Cancer Chemother Pharmacol 2010, 66:1113-1121.

57. Ramaswamy B, Phelps MA, Baiocchi R, Bekaii-Saab T, Ni W, Lai JP, Wolfson A, Lustberg ME, Wei L, Wilkins D, Campbell A, Arbogast D, Doyle A, Byrd JC, Grever MR, Shah MH: A dose-finding, pharmacokinetic and pharmacodynamic study of a novel schedule of flavopiridol in patients with advanced solid tumors. Invest New Drugs 2012, 30:629-638.

58. Wang LM, Ren DM: Flavopiridol, the first cyclin-dependent kinase inhibitor: recent advances in combination chemotherapy. Mini Rev Med Chem 2010, 10:1058-1070.

59. Bos PD, Nguyen DX, Massague J: Modeling metastasis in the mouse. Curr Opin Pharmacol 2010, 10:571-577.

60. Comen E, Norton L, Massague J: Clinical implications of cancer self-seeding. Nat Rev Clin Oncol 2011, 8:369-377.

61. Kim MY, Oskarsson T, Acharyya S, Nguyen DX, Zhang XH, Norton L, Massague J: Tumor self-seeding by circulating cancer cells. Cell 2009, 139:1315-1326.

62. Yu M, Ting DT, Stott SL, Wittner BS, Ozsolak F, Paul S, Ciciliano JC, Smas ME, Winokur D, Gilman AJ, Ulman MJ, Xega K, Contino G, Alagesan B, Brannigan BW, Milos PM, Ryan DP, Sequist LV, Bardeesy N, Ramaswamy S, Toner M, Maheswaran S, Haber DA: RNA sequencing of pancreatic circulating tumour cells implicates WNT signalling in metastasis. Nature 2012, 487:510-513.

63. Baccelli I, Schneeweiss A, Riethdorf S, Stenzinger A, Schillert A, Vogel V, Klein C, Saini M, Bauerle T, Wallwiener M, Holland-Letz T, Hofner T, Sprick M, Scharpff M, Marme F, Sinn HP, Pantel K, Weichert W, Trumpp A: Identification of a population of blood circulating tumor cells from breast cancer patients that initiates metastasis in a xenograft assay. Nat Biotechnol 2013, 31:539-544

64. Chen XQ, Stroun M, Magnenat JL, Nicod LP, Kurt AM, Lyautey J, Lederrey C, Anker P: Microsatellite alterations in plasma DNA of small cell lung cancer patients. Nat Med 1996, 2:1033-1035.

65. Leon SA, Shapiro B, Sklaroff DM, Yaros MJ: Free DNA in the serum of cancer patients and the effect of therapy. Cancer Res 1977, 37:646-650.

66. Nawroz H, Koch W, Anker P, Stroun M, Sidransky D: Microsatellite alterations in serum DNA of head and neck cancer patients. Nat Med 1996, 2:1035-1037.

67. Stroun M, Anker P, Maurice P, Lyautey J, Lederrey C, Beljanski M: Neoplastic characteristics of the DNA found in the plasma of cancer patients. Oncology 1989, 46:318-322.

68. Schwarzenbach $\mathrm{H}$, Hoon DS, Pantel K: Cell-free nucleic acids as biomarkers in cancer patients. Nat Rev Cancer 2011, 11:426-437.

69. Leary RJ, Kinde I, Diehl F, Schmidt K, Clouser C, Duncan C, Antipova A, Lee C, McKernan K, De La Vega FM, Kinzler KW, Vogelstein B, Diaz LA Jr, Velculescu VE: Development of personalized tumor biomarkers using massively parallel sequencing. Sci Trans/Med 2010, 2:20ra14.

70. McBride DJ, Orpana AK, Sotiriou C, Joensuu H, Stephens PJ, Mudie LJ, Hamalainen E, Stebbings LA, Andersson LC, Flanagan AM, Durbecq V, Ignatiadis M, Kallioniemi O, Heckman CA, Alitalo K, Edgren H, Futreal PA, Stratton MR, Campbell PJ: Use of cancer-specific genomic rearrangements to quantify disease burden in plasma from patients with solid tumors. Genes Chromosomes Cancer 2010, 49:1062-1069.

71. Diaz LA Jr, Williams RT, Wu J, Kinde I, Hecht JR, Berlin J, Allen B, Bozic I, Reiter JG, Nowak MA, Kinzler KW, Oliner KS, Vogelstein B: The molecular evolution of acquired resistance to targeted EGFR blockade in colorectal cancers. Nature 2012, 486:537-540.
72. Diehl F, Li M, Dressman D, He Y, Shen D, Szabo S, Diaz LA Jr, Goodman SN, David KA, Juhl H, Kinzler KW, Vogelstein B: Detection and quantification of mutations in the plasma of patients with colorectal tumors. Proc Nat/ Acad SciUA 2005, 102:16368-16373.

73. Diehl F, Schmidt K, Choti MA, Romans K, Goodman S, Li M, Thornton K, Agrawal N, Sokoll L, Szabo SA, Kinzler KW, Vogelstein B, Diaz LA Jr: Circulating mutant DNA to assess tumor dynamics. Nat Med 2008, 14:985-990.

74. Forshew T, Murtaza M, Parkinson C, Gale D, Tsui DW, Kaper F, Dawson SJ, Piskorz AM, Jimenez-Linan M, Bentley D, Hadfield J, May AP, Caldas C, Brenton $J D$, Rosenfeld N: Noninvasive identification and monitoring of cancer mutations by targeted deep sequencing of plasma DNA. Sci Trans/Med 2012, 4:136ra168

75. Misale S, Yaeger R, Hobor S, Scala E, Janakiraman M, Liska D, Valtorta E, Schiavo R, Buscarino M, Siravegna G, Bencardino K, Cercek A, Chen CT, Veronese S, Zanon C, Sartore-Bianchi A, Gambacorta M, Gallicchio M, Vakiani E, Boscaro V, Medico E, Weiser M, Siena S, Di Nicolantonio F, Solit D, Bardelli A: Emergence of KRAS mutations and acquired resistance to anti-EGFR therapy in colorectal cancer. Nature 2012, 486:532-536.

76. Heitzer E, Auer M, Hoffmann EM, Pichler M, Gasch C, Ulz P, Lax S, WaldispuehlGeigl J, Mauermann O, Mohan S, Pristauz G, Lackner C, Hofler G, Eisner F, Petru E, Sill H, Samonigg H, Pantel K, Riethdorf S, Bauernhofer T, Geigl JB, Speicher MR: Establishment of tumor-specific copy number alterations from plasma DNA of patients with cancer. Int J Cancer 2013, 133:346-356.

77. Chan KC, Jiang P, Zheng YW, Liao GJ, Sun H, Wong J, Siu SS, Chan WC, Chan SL, Chan AT, Lai PB, Chiu RW, Lo YM: Cancer genome scanning in plasma: detection of tumor-associated copy number aberrations, singlenucleotide variants, and tumoral heterogeneity by massively parallel sequencing. Clin Chem 2013, 59:211-224.

78. Heitzer E, Ulz P, Belic J, Gutschi S, Quehenberger F, Fischereder K, Benezeder T, Auer M, Pischler C, Mannweiler S, Pichler M, Eisner F, Haeusler M, Riethdorf S, Pantel K, Samonigg H, Hoefler G, Augustin H, Geigl JB, Speicher MR: Tumor associated copy number changes in the circulation of patients with prostate cancer identified through whole-genome sequencing. Genome Med 2013, 5:30.

79. Leary RJ, Sausen M, Kinde I, Papadopoulos N, Carpten JD, Craig D, O'Shaughnessy J, Kinzler KW, Parmigiani G, Vogelstein B, Diaz LA Jr, Velculescu VE: Detection of chromosomal alterations in the circulation of cancer patients with whole-genome sequencing. Sci Trans/ Med 2012, 4:162ra154.

80. Murtaza M, Dawson SJ, Tsui DW, Gale D, Forshew T, Piskorz AM, Parkinson C, Chin SF, Kingsbury Z, Wong AS, Marass F, Humphray S, Hadfield J, Bentley D, Chin TM, Brenton JD, Caldas C, Rosenfeld N: Non-invasive analysis of acquired resistance to cancer therapy by sequencing of plasma DNA. Nature 2013, 497:108-112.

81. Dawson SJ, Tsui DW, Murtaza M, Biggs H, Rueda OM, Chin SF, Dunning MJ, Gale D, Forshew T, Mahler-Araujo B, Rajan S, Humphray S, Becq J, Halsall D, Wallis M, Bentley D, Caldas C, Rosenfeld N: Analysis of circulating tumor DNA to monitor metastatic breast cancer. N Engl J Med 2013, 368:1199-1209.

82. Dawson SJ, Rosenfeld N, Caldas C: Circulating tumor DNA to monitor metastatic breast cancer. N Engl J Med 2013, 369:93-94.

83. Fabbri F, Carloni S, Zoli W, Ulivi P, Gallerani G, Fici P, Chiadini E, Passardi A, Frassineti GL, Ragazzini A, Amadori D: Detection and recovery of circulating colon cancer cells using a dielectrophoresis-based device: KRAS mutation status in pure CTCs. Cancer Lett 2013, 335:225-231.

84. Peeters DJ, De Laere B, Van den Eynden GG, Van Laere SJ, Rothe F, Ignatiadis M, Sieuwerts AM, Lambrechts D, Rutten A, van Dam PA, Pauwels P, Peeters M, Vermeulen PB, Dirix LY: Semiautomated isolation and molecular characterisation of single or highly purified tumour cells from CellSearch enriched blood samples using dielectrophoretic cell sorting. Br J Cancer 2013, 108:1358-1367.

doi:10.1186/gm477

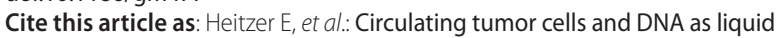
biopsies. Genome Medicine 2013, 5:73. 